\title{
PENGARUH PEMBERIAN IMUNOSTIMULAN DENGAN DOSIS BERBEDA TERHADAP PERTUMBUHAN IKAN KAKAP PUTIH (Lates calcarifer)
}

\author{
Intan Ria Ivandari, Linayati, Tri Yusufi Mardiana \\ Program Studi Budidaya Perairan Fakultas Perikanan Universitas Pekalongan
}

\begin{abstract}
The objectives for this research are to know the effects of immunostimulants and optimal doses to increase the growth of white snapper fish. This research was conducted from August 25, 2018 until September 27, 2018 in the Laboratory of Brackish Water at the Fisheries Faculty of Pekalongan University. The methods used was the Completely Randomized Design Method consisting of 4 treatments and 3 replications. The given is artificial feed which mixed with differents doses of imunostimulant, treatment consist of A $(0 \mathrm{ml} / \mathrm{kg}$ feed $)$, Treatment B $(5 \mathrm{ml} / \mathrm{kg}$ feed $)$, Treatment C (10 $\mathrm{ml} / \mathrm{kg}$ feed) and Treatment $\mathrm{D}(15 \mathrm{ml} / \mathrm{kg}$ feed). The seeds of white snapper fish are used for this research with size $4-5 \mathrm{~cm}$ and the density of 1 fish per liter. The parameters observed were biomass growth, daily specific growth rate $(\%)$, ratio of the amount of feed needed, efficiency of feed utilization (\%), degree of life (\%) and the water quality as supporting data. The research results showed that the given immunostimulant on the feed had an effects on the growth of white snapper fish, Calculated F $(13,474)>\mathrm{F}$ Table $5 \%(4,066)$ and the F Table 1\% $(7,591)$. The use of immunostimulant give the highest results on the biomass growth of white snapper fish on the Treatment D of 9,13 gram, FCR 0,92, EPP $42.86 \%$, SGR 3,31\%, and SR $100 \%$. The water quality during the research showed that the temperature range from $28-30 \mathrm{C}, \mathrm{pH}$ range is $7.0-7,4$, Dissolved Oxygen range is $5.2-7.2 \mathrm{ppm}$, Salinity range is $32-35 \mathrm{ppt}$ and Ammoniac range is $0.1-$ $0.3 \mathrm{ppm}$.
\end{abstract}

Keywords: White snapper fish seeds, Immunostimulants, Growth

\section{PENDAHULUAN}

Ikan kakap putih (Lates calcarifer, Bloch) atau seabass atau barramundi adalah salah satu ikan ekonomis penting di kawasan Asia dan Australia (Kueh 2012). Ikan kakap putih banyak dibudidayakan di Indonesia karena mempunyai nilai ekonomis yang tinggi, memiliki kisaran toleransi fisiologis yang cukup luas, fekunditas tinggi dan pertumbuhan yang cukup cepat. Peningkatan ikan kakap putih terus mengalami peningkatan dari tahun ke tahun. Pasar ikan kakap putih cukup luas, mulai dari pasar tradisional, rumah makan, restoran, hotel, pasar swalayan, hingga pasar ekspor (KKP, 2016).

Berdasarkan hasil observasi yang telah dilakukan di Balai Besar Perikanan Budidaya Air Payau (BBPBAP) Jepara, pada fase benih ikan kakap putih rentan terhadap penyakit. Pemberian imunostimulan menjadi salah satu cara untuk meningkatkan kekebalan tubuh ikan kakap putih terhadap penyakit. Metode pencegahan penyakit dianggap lebih aman dengan menggunakan imunostimulan dan dapat menciptakan budidaya perikanan yang berkelanjutan untuk meningkatkan pertumbuhan ikan kakap putih. Namun diperlukan satu penelitian tentang dosis imunostimulant yang tepat agar dapat memberikan imunostimulant

Imunostimulan merupakan suatu zat yang termasuk dalam adjuvan, mempunyai kemampuan untuk meningkatkan ketahanan tubuh terhadap infeksi (Ellis, 1998). Imunostimulan yang digunakan pada penelitian ini mengandung sorbitol, ekstrak echinaceae, temulawak, vitamin $\mathrm{C}$, magnesium, komponen vitamin $\mathrm{B}$ komplek, dan nicotinamide. Beberapa hasil penelitian telah memperlihatkan bahwa imunostimulan yang 
ditambahkan dalam pakan dapat meningkatkan resistensi ikan dan udang terhadap infeksi penyakit melalui peningkatan respon imun non-spesifik sekaligus meningkatkan pertumbuhan ikan (Pais et al., 2008), pada ikan kakap putih (Lates calcalifer) (Noviardi et al.,2014), pada udang vannamei (Litopenaeus vannamei) (Ridlo, 2012).

Tujuan dari penelitian ini untuk mengetahui pengaruh pemberian imunostimulan dalam meningkatkan pertumbuhan dan mengetahui dosis yang efektif pada pertumbuhan ikan kakap putih.

\section{TINJAUAN PUSTAKA}

Imunostimulan merupakan suatu zat yang termasuk dalam adjuvan, mempunyai kemampuan untuk meningkatkan ketahanan tubuh terhadap infeksi (Ellis, 1998). Pemanfaatan imunostimulan dalam kegiatan budidaya dapat mengoptimalkan produksi budidaya melalui peningkatan ketahanan tubuh ikan atau udang windu terhadap penyakit infeksi (Alifuddin 1999). Komposisi yang terdapat dalam imunogravieto antara lain Bio ATP, sorbitol, ekstrak echinaceae, temulawak, vitamin C, magnesium, komponen vitamin B komplek, dan nicotinamide. Kandungan utama imunogravieto adalah temulawak yang mengandung kurkuminoid, mineral, minyak Atsiri serta minyak lemak. Selain itu, temulawak juga mengandung zat gizi antara lain karbohidrat, protein, dan lemak serat serat kasar mineral seperti Kalium (K), Natrium (Na), Magnesium (Mg), zat besi (Fe), Mangan $(\mathrm{Mn})$ dan cadmium $(\mathrm{Cd})$. Kompenen utama kandungan zat yang terdapat dalam rimpang temulawak adalah zat kuning yang disebut kurkumin dan juga protein, pati serta zat-zat minyak Atsiri (Noviardi dkk, 2010).

\section{METODE PENELITIAN}

Penelitian dilaksanakan pada tanggal 25 Agustus 2018 hingga 27 September 2018 di Laboratorium Air Payau, Fakultas Perikanan, Universitas Pekalongan.

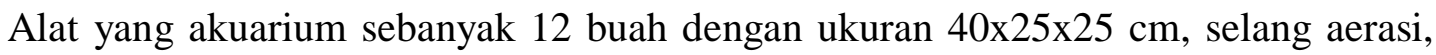
batu aerasi, timbangan analitik, scopnet, penggaris, blower, termometer, refraktometer, selang sipon, $\mathrm{pH}$ meter dan kamera.

Bahan yang digunakan adalah benih ikan kakap putih sebanyak 60 ekor, dengan ukuran 4-5 cm/ekor, dan imunostimulan (imuno gravito).

Metode penelitian yang digunakan adalah metode Rancangan Acak Lengkap (RAL) yang terdiri atas 4 Perlakuan dan 3 ulangan. Perlakuan yang akan diuji adalah penambahan imunostimulan pada pakan buatan dengan dosis sebagai berikut :

A : Pakan tanpa imunostimulan

$\mathrm{B}: 5 \mathrm{ml}$ imunostimulan / $\mathrm{kg}$ pakan

$\mathrm{C}: 10 \mathrm{ml}$ imunostimulan / $\mathrm{kg}$ pakan

$\mathrm{D}: 15 \mathrm{ml}$ imunostimulan / $\mathrm{kg}$ pakan

Prosedur penelitian meliputi tahap persiapan penelitian menyiapkan peralatan dan bahan yang akan digunakan selama penelitian, seperti mencuci, menata dan memasang instalasi aerasi pada setiap akuarium kemudian mengisi air yang akan digunakan sebagai media penelitian. Kemudian akuarium diisi air sebanyak 5 liter.

Pencampuran imunostimulan ke dalam pakan komersil dengan cara di spray kemudian di angin-anginkan. Frekuensi pemberiaan pakan dilakukan sebanyak 3 kali sehari dengan rentang waktu pagi, siang, dan sore hari. Pemberian pakan yang dilakukan yaitu secara at satiation hal ini sesuai dengan SNI (2014). 
Parameter yang diamati dalam penelitian ini adalah data pertumbuhan biomassa, laju pertumbuhan harian (SGR), Efisiensi Pemanfaatan Pakan (EPP), FCR (Food Convertion Ratio) dan SR (Survival Rate) dan kualitas air media pemeliharaan sebagai data pendukung.

1. Pertumbuhan

Pertambahan biomassa dapat dihitung dengan menggunakan rumus (Effendie,1997) yaitu :

$$
\mathbf{W}=\mathbf{W t}-\mathbf{W o}
$$

Keterangan :

W : Pertambahan biomassa benih ikan kakap putih (gram)

Wt : Biomassa benih ikan kakap putih akhir penelitian (gram)

Wo : Biomassa benih ikan kakap putih awal penelitian (gram)

\section{SGR (Specifik Growth Rate)}

Penghitungan laju pertumbuhan harian digunakan rumus yang dikemukakan oleh Effendi (1997), sebagai berikut :

$$
\text { SGR }=(\text { Ln Wt }- \text { Ln Wo }) / t \times 100 \%
$$

Keterangan :

SGR : Laju Pertumbuhan Harian (\%)

Wt : Biomassa benih ikan kakap putih akhir penelitian (gram)

Wo : Biomassa benih ikan kakap putih awal penelitian (gram)

t : Lama pemeliharaan (hari)

3. Efesiensi Pemanfaatan pakan (EPP)

Efisiensi pemanfaatan pakan dapat dihitung menggunakan rumus menurut Effendi (1997) yaitu :

$$
\mathrm{EP}=\frac{\mathrm{Wt}-\mathrm{Wo}_{0}}{\mathrm{~F}} \times 100 \%
$$

Keterangan :

EP : Efisiensi pakan

Wt : Biomassa benih ikan kakap putih akhir penelitian (gram)

Wo : Biomassa benih ikan kakap putih awal penelitian (gram)

F : Jumlah total pakan yang diberikan

4. FCR (Food Convertion Ratio)

FCR atau konversi pakan dapat dihitung dengan rumus Effendi (1997), yaitu :

$$
F C R=\frac{F}{W t-W o}
$$

Keterangan:

FCR : Food Convertion Ratio

F : Jumlah pakan yang dikonsumsi

Wo : Bobot biomassa ikan kakap putih pada awal penelitian (gram)

Wt : Bobot biomassa ikan kakap putih pada akhir penelitian (gram) 
5. SR (Survival Rate)

Kelangsungan hidup ikan dihitung meneurut Effendi (1997), sebagai berikut :

$$
\mathrm{SR}=\frac{\mathrm{Nt}}{\mathrm{No}} \times 100 \%
$$

Keterangan:

SR : Kelangsungan hidup (\%).

No : Jumlah ikan diawal penelitian (ekor)

$\mathrm{Nt} \quad$ : Jumlah ikan diakhir penelitian (ekor)

6. Kualitas Air

Pengukuran kualitas air bertujuan untuk mengetahui kelayakan air sebagai media hidup bagi kehidupan benih ikan kakap putih. Pengamatan kualitas air yang tertera selama penelitan meliputi suhu air, oksigen terlarut, dan $\mathrm{pH}$.

Hipotesis yang digunakan dalam penelitian ini adalah :

$\mathrm{H}_{0}=$ Pemberian imunostimulan dalam pakan dengan dosis berbeda diduga tidak memberikan pengaruh berbeda terhadap pertumbuhan ikan kakap putih.

$\mathrm{H}_{1}=$ Pemberian imunostimulan dalam pakan dengan dosis berbeda diduga memberikan pengaruh yang berbeda terhadap pertumbuhan ikan kakap putih

Data yang diperoleh dari hasil sampling per sepuluh hari dicatat, dikumpulkan dan ditabulasi. Data tersebut kemudian dihitung untuk menentukan parameter pertumbuhan dan biomassa. Untuk menjawab hipotesis yang diajukan dilakuan uji statistik yakni ANOVA (pada selang kepercayaan 99\%). Akan tetapi sebelumnya dilakukan analisis uji normalitas dan homogenitas. Jika data yang diperoleh berbeda nyata maka selanjutnya dilakukan uji lanjutan yaitu menggunakan uji tukey (Sastrosupadi, 1995). Pengolahan pengujian data menggunakan bantuan program Microsoft Excel.

\section{HASIL DAN PEMBAHASAN}

\subsection{Hasil}

\subsubsection{Pertumbuhan}

Pengamatan laju pertumbuhan benih ikan kakap putih diketahui melalui pengukuran biomassa benih setiap sepuluh hari sekali. Berdasarkan sampling yang dilakukan selama kegiatan penelitian, diperoleh data pertumbuhan biomassa setiap minggu yang disajikan pada Tabel 1 .

Tabel 1. Data Pertambahan Biomassa Ikan Kakap Putih Selama Penelitian

\begin{tabular}{c|c|c|c|c}
\multirow{2}{*}{ Ulangan } & \multicolumn{4}{|c}{ Perlakuan } \\
\cline { 2 - 5 } & $\mathrm{A}$ & $\mathrm{B}$ & $\mathrm{C}$ & $\mathrm{D}$ \\
\hline 1 & 6,40 & 6,00 & 5,50 & 9,30 \\
2 & 6,30 & 6,30 & 7,40 & 8,70 \\
3 & 5,30 & 6,60 & 7,40 & 9,40 \\
\hline Jumlah & 18,00 & 18,90 & 20,30 & 27,40 \\
\hline Rerata & 6,00 & 6,30 & 6,77 & 9,13
\end{tabular}

Berdasarkan Tabel 1, dapat diketahui bahwa pertumbuhan ikan kakap putih menggalami peningkatan sepuluh hari. Pertumbuhan dengan hasil 
biomassa tertinggi ditunjukkan pada perlakuan $\mathrm{D}$ dengan dosis pemberian imunostimulan $15 \mathrm{ml} / \mathrm{kg}$ pakan nilai biomassa sebesar 9,13 gram. Kemudian diikuti oleh perlakuan $\mathrm{C}$ dengan dosis pemberian imunostimulan $10 \mathrm{ml} / \mathrm{kg}$ pakan nilai biomassa sebesar 6,77 gram perlakuan B dengan dosis pemberian imunostimulan $5 \mathrm{ml} / \mathrm{kg}$ pakan dengan nilai biomassa sebesar 6,30 gram dan A dengan dosis pemberian imunostimulan $0 \mathrm{ml} / \mathrm{kg}$ pakan nilai biomassa sebesar 1,679 gram. Grafik biomassa ikan kakap putih yang diperoleh selama penelitian disajikan pada gambar 1.

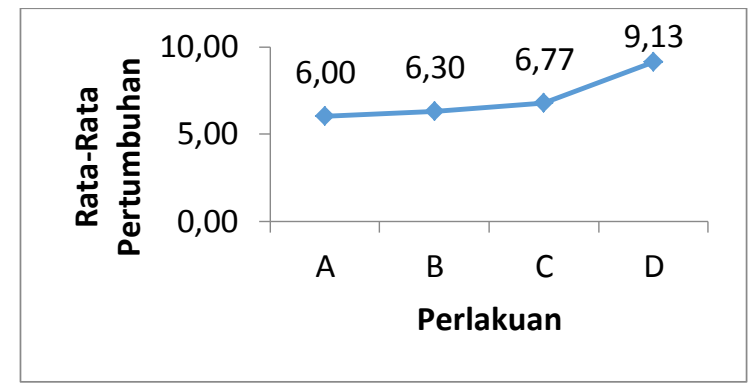

Gambar 1. Grafik Pertumbuhan Ikan Kakap Putih (Penelitian, 2018)

Hasil uji normalitas didapatkan berdasarkan hasil perhitungan data pertumbuhan ikan kakap putih selama penelitian. Hasil perhitung uji normalitas diperoleh bahwa nilai $\mathrm{L} \max (0,209)<\mathrm{L}$ tabel $5 \%$ dan $1 \%<(0,5987$ dan 0,5812) menunjukan bahwa pemberian imunostimulan dengan dosis yang berbeda terhadap pertumbuhan ikan kakap putih tersebut berdistribusi normal. Hasil uji homogenitas diperoleh bahwa nilai $X^{2}(3,9609)<X^{2}$ tabel $5 \%$ dan $1 \%$ (7,815 dan 9,210) menunjukan bahwa pemberian imunostimulan dengan dosis yang berbeda terhadap pertumbuhan ikan kakap putih tersebut bersifat homogen.

Tabel 2. Daftar Analisis Ragam Pertumbuhan Biomassa Benih Ikan Kakap Putih

\begin{tabular}{lcccccc}
\multicolumn{1}{c}{ SK } & DB & JK & KT & $\begin{array}{c}\text { F } \\
\text { Hitung }\end{array}$ & $\begin{array}{c}\text { Tabel } \\
\end{array}$ \\
\hline & & & & & $5 \%$ & $1 \%$ \\
\hline Perlakuan & 3 & 18,257 & 6,09 & $* *$ & 4,066 & 7,591 \\
Galat & 8 & 3,61 & 0,45 & & & \\
\hline Total & 11 & 21,87 & & & & \\
Keterangan : ** berbeda sangat nyata & & &
\end{tabular}

Hasil analisis ragam terhadap pertumbuhan bobot ikan kakap putih didapatkan hasil bahwa nilai $\mathrm{F}$ hitung lebih besar dari nilai $\mathrm{F}$ tabel $5 \%$ dan $\mathrm{F}$ tabel $1 \%$, dengan nilai $\mathrm{F}$ hitung $(13,474)>\mathrm{F}$ tabel $5 \%(4,066)$ dan $\mathrm{F}$ tabel $1 \%$ $(7,591)$ yang berarti bahwa pemberian imunostimulan dengan dosis yang berbeda terhadp pertumbuhan ikan kakap putih memberi pengaruh nyata terhadap pertambahan bobot ikan kakap putih. maka selanjutnya dilakukan uji lanjut yaitu uji Tukey (Tabel 3). 
Tabel 3. Daftar Nilai Ragam Uji Tukey

\begin{tabular}{|c|c|c|c|c|c|}
\hline Perlakuan & Rerata & & Selisi & & \\
\hline & & $\mathrm{D}$ & $\mathrm{C}$ & B & A \\
\hline $\mathrm{D}$ & 9,13 & - & & & \\
\hline $\mathrm{C}$ & 6,77 & $2,36^{* *}$ & - & & \\
\hline B & 6,3 & $2,83 * *$ & $0,47 * *$ & - & \\
\hline A & 6 & $3,13 * *$ & $0,77 * *$ & $0,3 * *$ & - \\
\hline
\end{tabular}

Hasil uji tukey, menunjukkan bahwa pemberian imunostimulan dengan dosis yang berbeda terhadap pertumbuhan ikan kakap putih memberikan pengaruh pertumbuhan terhadap ikan kakap putih. Hasil uji tukey menunjukkan bahwa perlakuan D (dosis $15 \mathrm{ml} / \mathrm{kg}$ pakan) menghasilakan nilai rerata pertumbuhan yang paling tinggi dengan nilai 9,13 gram, lalu dikuti dengan perlakuan $\mathrm{C}$ (dosis $10 \mathrm{ml} / \mathrm{kg}$ pakan) dengan nilai rerata sebesar 6,17 gram, perlakuan B (dosis $5 \mathrm{ml} / \mathrm{kg}$ pakan) dengan nilai rerata 6,3 gram dan perlakuan A (dosis $0 \mathrm{ml} / \mathrm{kg}$ pakan) dengan nilai rerata 6 gram.

\subsubsection{SGR (Specifik Growth Rate)}

Berdasarkan data tersebut laju pertumbuhan spesifik ikan kakap putih tersaji pada Tabel 4.

Tabel 4. Laju Pertumbuhan Harian (\%)

\begin{tabular}{ccccc}
\hline \multirow{2}{*}{ Ulangan } & \multicolumn{4}{c}{ Perlakuan } \\
\cline { 2 - 5 } & $\mathrm{A}$ & $\mathrm{B}$ & $\mathrm{C}$ & $\mathrm{D}$ \\
\hline 1 & 2,54 & 2,49 & 2,22 & 3,38 \\
2 & 2,65 & 2,68 & 3,11 & 3,20 \\
3 & 2,38 & 2,97 & 2,99 & 3,36 \\
\hline Jumlah & 7,56 & 8,14 & 8,32 & 9,94 \\
\hline Rerata & 2,52 & 2,71 & 2,77 & 3,31 \\
\hline
\end{tabular}

Berdasarkan tabel di atas dapat diketahui bahwa laju pertumbuhan bobot spesifik ikan kakap putih tertinggi diperoleh pada perlakuan D (dosis imunostimulan $15 \mathrm{ml} / \mathrm{kg}$ pakan) dengan nilai rerata sebesar 3,31\%, diikuti oleh perlakuan $\mathrm{C}$ (dosis imunostimulan $10 \mathrm{ml} / \mathrm{kg}$ pakan) dengan nilai rerata sebesar 2,77\%, kemudian pada B (dosis imunostimulan $5 \mathrm{ml} / \mathrm{kg}$ pakan) dan perlakuan A (kontrol) dengan nilai rerata sebesar $2,52 \mathrm{ml} / \mathrm{kg}$ pakan.

\subsubsection{Efisiensi Pemanfaatan Pakan}

Data efisiensi pemanfaatan pakan ikan kakap putih tersaji pada Tabel 5.

Tabel 5. Efisiensi Pemanfaatan Pakan Ikan Kakap Putih

\begin{tabular}{ccccc}
\hline Perlakuan & A & B & C & D \\
\hline Wo & 15.9 & 15.1 & 15.7 & 16.1 \\
Wt & 33.9 & 34 & 36 & 43.5 \\
F & 21,3 & 22,7 & 22 & 25,3 \\
EPP $\%$ & 33.15 & 33.33 & 35.29 & 42.86
\end{tabular}

Berdasarkan Tabel 5, dapat diketahui bahwa efisiensi pemanfaatan pakan ikan kakap putih terbaik diperoleh pada perlakuan D (dosis 
imunostimulan $15 \mathrm{ml} / \mathrm{kg}$ pakan) dengan nilai EPP terbesar (42.86\%). Kemudian diikuti oleh perlakuan $\mathrm{C}$ (dosis imunostimulan $10 \mathrm{ml} / \mathrm{kg}$ pakan) dengan nilai EPP sebesar (35.29\%), perlakuan B (dosis imunostimulan $5 \mathrm{ml} / \mathrm{kg}$ pakan) dengan niali EPP sebesar (33.33\%) dan perlakuan A (kontrol) dengan nilai EPP sebesar (33.15\%).

\subsubsection{Food Convertion Ratio (FCR)}

Data Food Convertion Ratio Ratio ikan kakap putih yang didapatkan selama penelitian tersaji pada Tabel 6 .

Tabel 6. Data Food Convertion Ratio Ratio ikan kakap putih

\begin{tabular}{lrrrc}
\hline Perlakuan & \multicolumn{1}{c}{ A } & \multicolumn{1}{c}{ B } & \multicolumn{1}{c}{ C } & D \\
\hline Wo & 15,9 & 15,1 & 15.7 & 16.1 \\
Wt & 33.9 & 34 & 36 & 43.5 \\
F & 29 & 22,7 & 22 & 25,3 \\
FCR & 1.18 & 1.2 & 1.08 & 0.92 \\
\hline
\end{tabular}

Berdasarkan tabel 6, dapat diketahui bahwa nilai FCR pada ikan kakap putih terbaik diperoleh pada perlakuan D (dosis imunostimulan $15 \mathrm{ml} / \mathrm{kg}$ pakan) dengan nilai FCR sebesar 0.92. Kemudian diikuti oleh perlakuan C (dosis imunostimulan $10 \mathrm{ml} / \mathrm{kg}$ pakan) dengan nilai FCR sebesar 1.08 perlakuan B (dosis imunostimulan $5 \mathrm{ml} / \mathrm{kg}$ pakan) dengan nilai FCR sebesar 1.2 dan pelakuan A (kontrol) dengan nilai FCR 1.8.

\subsubsection{Survival Rate (SR)}

Data Survival Rate (SR) ikan kakap putih tersaji tabel 7.

Tabel 7. Survival Rate (SR \%)

\begin{tabular}{lrrrr}
\hline Perlakuan & \multicolumn{1}{c}{ A } & \multicolumn{1}{c}{ B } & \multicolumn{1}{c}{ C } & \multicolumn{1}{c}{ D } \\
\hline No & 15 & 15 & 15 & 15 \\
Nt & 14 & 15 & 15 & 15 \\
SR & $93 \%$ & $100 \%$ & $100 \%$ & $100 \%$ \\
\hline
\end{tabular}

Dari tabel 7, dapat dilihat bahwa derajat kelangsungan hidup ikan kakap putih pada perlakuan $\mathrm{B}$, perlakuan $\mathrm{C}$, dan perlakuan $\mathrm{D}$ diperoleh nilai derajat kelangsungan hidup ikan kakap putih sebesar $100 \%$ dan pada perlakuan A (kontrol) diperoleh nilai SR sebesar 93\%.

4.1.6. Kualitas Air

Parameter kualitas air yang diukur selama penelitian adalah suhu air, pH, oksigen terlarut, salinitas, dan amoniak. Pengukuran kualitas air dilakukan setiap minggu. Nilai kisaran parameter kualitas air selama penelitian berkisar suhu $28-30^{\circ} \mathrm{C}, \mathrm{pH}$ air berkisar antara 7,0 - 7,4, oksigen terlarut 5,2 - 7,2 ppm, salinitas $32-35$ ppt dan amonniak 0,1 - 0,3 ppm. Selama masa penelitian berlangsung dilakukan pengontrolan terhadap kualitas air dengan cara melakukan penyifonan setiap dua hari sekali. 


\subsection{Pembahasan}

\subsubsection{Pertumbuhan}

Pertumbuhan adalah pertambahan ukuran panjang atau berat dalam satu waktu, akibat terjadinya pembelahan sel secara mitosis yang disebabkan oleh kelebihan jumlah input energi dan asam amino yang berasal dari makanan (Rahardjo,dkk., 2000). Pemberian imunostimulan dengan dosis tertinggi (15 ml / kg pakan) pada perlakuan D memberikan bobot biomassa dengan nilai biomassa sebesar 9.23 gram. Sedangkan pada laju pertumbuhan bobot spesifik harian ikan kakap putih didapatkan hasil tertinggi pada perlakuan D (dosis imunostimulan $15 \mathrm{ml} / \mathrm{kg}$ pakan) dengan nilai rerata $3.31 \%$. Hal ini disebabkan bahwa semakin besar dosis imunostimulan yang ditambahkan ke dalam pakan dapat meningkatkan mekanisme respon imunitas ikan. Kandungan yang tedapat pada imunostimulan yaitu kandungan temulawak. Temulawak memiliki kandungan minyak atsiri dan kandungan kurkumin yang dapat memacu pertumbuhan dan membantu pencernaan sehingga nafsu makan ikan kakap putih meningkat dan pencernaan menjadi optimal, selain itu temulawak memiliki antibakteri yang dapat melisiskan racun yang menempel pada dinding usus, sehingga penyerapan nutrisi lebih baik dan dapat memicu pertumbuhan (Samsundari, 2006).

Pada perlakuan $\mathrm{C}$ dengan pemberian dosis imunostimulan $10 \mathrm{ml} / \mathrm{kg}$ pakan nilai biomassa yang dihasilkan sebesar 6.77 gram, diikuti dengan perlakuan B dengan dosis $5 \mathrm{ml} / \mathrm{kg}$ pakan dengan nilai biomassa yang dihasilkan sebesar 6.30 gram. Perlakuan C dan B memiliki nilai yang lebih rendah dibandingkan dengan perlakuan $\mathrm{D}$. Rendahnya pertambahan bobot biomassa pada perlakuan $\mathrm{C}$ dan $\mathrm{B}$ disebabkan karena rendahnya dosis imunostimulan yang diberikan. Imunostimulan yang digunakan mengandung komposisi inositol sebagai penyumbang insulin dalam tubuh ikan, karena dosis yang digunakan lebih rendah dibandingkan perlakuan D, mengakibatkan sistem kerja insulin tidak optimal. Kebutuhan energi dapat terpenuhi apabila glukosa dalam darah dapat segera masuk kedalam sel, dan ini tergantung pada kinerja insulin. Apabila kinerja insulin meningkat, maka masuknya glukosa ke dalam sel akan lebih efektif sehingga glukosa tersedia sebagai sumber energi. Hal ini sesuai dengan.

Pada perlakuan A dengan dosis $0 \mathrm{ml} / \mathrm{kg}$ pakan memiliki nilai rata-rata bobot yang paling rendah dibandingkan perlakuan lainnya, nilai biomassa yang dihasilkan dari perlakuan A yaitu 6.00 gram. Dilihat dari hasil laju pertumbuhan bobot spesifik harian ikan kakap putih terendah pada perlakuan A dengan nilai reta-rata sebesar 2,52\%. Hal ini disebabkan karena pakan yang diberikan tidak mengandung imunostimulan (kandungan temulawak) sehingga ikan kakap putih pada perlakuan A memiliki nafsu makan yang lebih rendah dibandingkan perlakuan lainnya dan laju pengosongan lambung ikan pada perlakuan A lebih lambat. Hal ini sesuai dengan pendapat (Wijayakusuma, 2003) bahwa kandungan temulawak dalam imunostimulan berpengaruh pada pankreas dan meningkatan nafsu makan dan dapat mempercepat pengosongan lambung, dengan demikian akan timbul rasa lapar dan merangsang nafsu makan. 


\subsubsection{Efisiensi Pemanfaatan Pakan}

Efisiensi pakan adalah perbandingan antara pertambahan bobot badan yang dihasilkan dengan jumlah pakan yang dikonsumsi. Penggunaan pakan menunjukkan banyaknya pertambahan bobot badan yang dihasilkan dari satu kilogram pakan yang diberikan. Efisiensi pakan merupakan kebalikan dari konversi pakan, semakin tinggi nilai efisiensi pakan maka jumlah pakan yang diperlukan untuk menghasilkan satu kilogram daging akan semakin sedikit.

Tingkat efisiensi pakan mengalami kenaikan seiring dengan meningkatnya dosis imunostimulan yang diberikan. Efisiensi pemanfaatan pakan ikan kakap putih terbaik diperoleh pada perlakuan D sebesar $42.86 \%$. Pada perlakuan D dosis imunostimulan yang ditambahkan kedalam pakan merupakan dosis tertinggi, yang artinya pemberian imunostimulan dengan dosis $15 \mathrm{ml} / \mathrm{kg}$ pakan memberikan pengaruh terhadap efisiensi pemanfaatan pakan ikan kakap putih. Tingginya nilai efisiensi pakan pada perlakuan D disebabkan karena terdapat kandungan sorbitol di dalam imunostimulan sebagai gugus gula yang berfungsi pada hati, pankreas, merangsang sekresi dan memperkaya getah pankreas dengan enzim-enzim pencernaan serta menormalkan fungsi usus. Hal ini didukung oleh pernyataan Nilai efisiensi pemanfaatan pakan yang diperoleh pada perlakuan C (35.29\%) dan perlakuan B $333.33 \%)$ lebih rendah dibandingkan perlakuan D (42.86\%) hal ini diduga karena asupan energi yang diperoleh dari pakan hanya sebagian kecil yang dapat digunakan untuk kebutuhan pokok, hal tersebut juga dapat dilihat dari bobot biomassa yang diperoleh pada perlakuan C (6.77 gram), perlakuan B (6.30 gram) sedangkan pada perlakuan D bobot biomassa sebesar (9.13 gram). Nilai efisiensi yang paling rendah yaitu pada perlakuan A (kontrol) dengan nilai efisiensi pakan sebesar $33.15 \%$ dikarenakan tidak optimalnya kemampuan ikan dalam mencerna dan mengabsorsi pakan sebagai akibat dari tidak optimalnya dosis imunostimulan yang diberikan.

\subsubsection{FCR (Food Convertion Ratio)}

Konversi pakan merupakan perbandingan antara jumlah pakan yang diberikan dengan jumlah bobot ikan yang dihasilkan. Semakin kecil nilai konversi pakan berarti tingkat efisiensi pemanfaatan pakan lebih baik, sebaliknya apabila konversi pakan besar, maka nilai efisiensi pemanfaatan pakan kurang baik.

Nilai konversi pakan menunjukkan seberapa besar pakan yang dikonsumsi menjadi biomassa tubuh ikan. Berdasarkan hasil penelitian konversi pakan yang dihasilkan pada perlakuan A (1.18), perlakuan B (1.20), perlakuan C (1.08) dan perlakuan D (0.92). Penambahan imunostimulan dengan dosis berbeda ke dalam pakan memberikan hasil FCR yang baik bagi perlakuan A, perlakuan B, perlakuan C maupun perlakuan D. Hal ini dikarenakan pakan dapat dicerna oleh pencernaan dengan bantuan enzim-enzim yang merubah senyawa komplek menjadi senyawa sederhana dengan singkat, sehingga ikan mampu memanfaatkan pakan dengan optimal. Semakin rendah nilai FCR maka pemanfaatan pakan semakin bagus. Hal ini sesuai dengan pendapat (Melianawati dan K. Sewirya 2010) bahwa semakin kecil tingkat konversi pakan 
menunjukkan jumlah pakan yang diberikan semakin efektif untuk pertumbuhan ikan, sebaliknya semakin besar tingkat konversi pakan yang diberikan menunjukkan bahwa jumlah pakan yang diberikan kurang efektif untuk pertumbuhan.

\subsubsection{Survival Rate}

Kelangsungan hidup atau disebut juga dengan survival rate merupakan persentase ikan uji yang hidup pada akhir pemeliharaan dalam suatu wadah. Effendi (1997), bahwa tingkat kelangsungan hidup merupakan nilai persentase jumlah ikan yang hidup selama periode pemeliharaan.

Kelangsungan hidup ikan kakap putih tertinggi selama penelitian yaitu pada perlakun B, C dan D dengan derajat kehidupan ikan 100\%. Hal ini menunjukkan bahwa ikan kakap putih tidak mengalami kematian pada saat pemeliharaan.Tingginya kelangsungan hidup pada perlakuan $\mathrm{B}, \mathrm{C}$ dan $\mathrm{D}$ dikarenakan pemberian imunostimulan yang ditambahkan ke dalam pakan dapat meningkatkan persentase kehidupan bagi ikan. Komposisi imunostimulan yang digunakan di dalam penelitian mengandung vitamin $\mathrm{C}$ yang dapat mencukupi nutrien dari pakan uji untuk mempertahankan kelangsungan hidup ikan. Sandes (1991), mengemukakan bahwa vitamin C berperan penting dalam membantu reaksi tubuh terhadap stress fisiologi, pencegahan penyakit dan penting untuk pertumbuhan. Hal yang sama juga dikemukakan Suwirya et al., (2001), bahwa vitamin $\mathrm{C}$ dibutuhkan tubuh ikan untuk meningkatkan metabolisme, daya tahan terhadap perubahan lingkungan dan penyakit.

Sedangkan pada perlakuan A (kontrol) derajat kehidupan ikan kakap putih yang dihasilkan sebesar 93\%. Hal ini dikarenakan pakan yang diberikan tidak mengandung tambahan vitamin $\mathrm{C}$ yang terkandung di dalam imunostimulan. Ikan yang mengalami kekurangan vitamin $\mathrm{C}$ dalam pakan akan menyebabkan gangguan dan penyakit, salah satunya penyakit anemia.. Gejala yang sering timbul akibat anemia adalah kurangnya nafsu makan pada ikan, warna tubuh pucat, terdapat jamur serta ikan tidak bergerak secara aktif. Vitamin berfungsi sebagai imunitas atau meningkatkan kemampuan tubuh ikan agar terhindar dari penyakit (Sandes,1991). Kondisi ikan kakap putih selama penelitian untuk semua perlakuan disajikan pada Tabel 8.

Tabel 8. Kondisi ikan kakap putih

\begin{tabular}{ccccc}
\hline \multirow{2}{*}{ Minggu ke - } & \multicolumn{4}{c}{ Perlakuan } \\
\cline { 2 - 5 } & A & B & C & D \\
\hline 1 & $3+$ & $2+$ & $2+$ & $1+$ \\
2 & $7+$ & $5+$ & $4+$ & $3+$ \\
3 & $12+$ & $9+$ & $7+$ & $6+$ \\
4 & $14+$ & $11+$ & $7+$ & $6+$ \\
\hline
\end{tabular}

Keterangan : + (ikan berjamur)

Kondisi ikan kakap putih selama penelitian berlangsung mengalami terserangnya jamur pada tubuh ikan. Pada perlakuan A ikan kakap putih yang terserang jamur setiap minggunya mengalami peningkatan, dan mengakibatkan kematian satu ekor ikan kakap putih pada masa akhir pemeliharaan sehingga derajat hidup yang dihasilkan sebesar 93\%. Hal ini dikarenakan pada perlakuan 
A pakan tidak mengandung (vitamin C). Akibat tidak adanya tambahan vitamin C pada perlakuan A maka tidak ada asupan energi tambahan yang dapat meminimalkan jumlah ikan yang terserang jamur dan mengakibatkan kematian. Vitamin $\mathrm{C}$ berfungsi sebagai zat antioksidan.

Pada perlakuan B, C dan D kondisi ikan kakap putih selama penelitian pun terserang oleh jamur. Jumlah ikan kakap putih yang terserang jamur pada perlakuan B dan C lebih banyak dibandingkan pada perlakuan D untuk setiap minggunya namun tidak mengakibatkan kematian dan menghasilkan derajat kehidupan sebesar $100 \%$ pada masing-masing perlakuan. Hal ini dikarenakan pada perlakuan B, C, dan D pakan yang diberikan mengandung imunostimulan (Vitamin C) yang mempunyai peran dalam pembentukan hemoglobin dalam darah, dimana vitamin $\mathrm{C}$ membantu penyerapan zat besi dari makanan sehingga dapat diproses menjadi sel darah merah kembali. Dengan meningkatkan hemoglobin dalam darah maka asupan makanan dan oksigen dalam darah dapat diedarkan ke seluruh jaringan tubuh yang akhirnya dapat mendukung kelangsungsungan hidup dan pertumbuhan ikan.

Selain vitamin $\mathrm{C}$, imunostimulan terdapat kandungan Echinacea yang bemanfaat dalam pengobatan penyakit infeksi disebabkan kemampuannya untuk berperan sebagai anti inflamasi dan imunostimulan. Echinacea dapat memacu aktivitas limfosit, meningkatkan fagositosis dan menginduksi produksi interferon (Tyler,1995 dalam Craig, 1999). Ekstrak Echinacea berguna sebagai imununodulator sehingga dapat memperbaiki daya tahan tubuh. Terdapat kandungan polisakarida di dalam Echinacea yang berfungsi untuk menstimulasi sistem kekebalan tubuh dan regenerasi jaringan yang rusak serta meningkatkan jumlah sel (Burick et al., 1997).

\section{SIMPULAN DAN SARAN}

\subsection{Simpulan}

Berdasarkan hasil penelitian yang telah dilaksanakan, maka dapat disimpulkan bahwa :

a) Pemberian imunostimulan dengan dosis berbeda yang ditambahkan pada pakan memberikan pengaruh yang sangat nyata terhadap pertumbuhan ikan kakap putih.

b) Pertumbuhan terbaik diperoleh pada perlakuan D (Dosis $15 \mathrm{ml} / \mathrm{kg}$ pakan) dengan nilai rata-rata bobot sebesar 9.13 gram.

c) Kualitas air selama penelitian berada di kisaran optimum untuk kelangsungan ikan kakap putih.

\subsection{Saran}

Disaran untuk memberikan imunostimulant dengan dosis $15 \mathrm{ml} / \mathrm{Kg}$ pakan dalam budidaya ikan Kakap Putih agar dapat meningkatkan pertumbuhan ikan tersebut. 


\section{DAFTAR PUSTAKA}

Alifuddin, M. 1999. Peran Imunostimulan (Lipopolisakarida, Saccharomyces cere-visiae and Levamisol) terhadap Peningkatan Respons Imunitas Ikan Jambal Siam (Pangasius hypopthalmus). Tesis. Progr Studi Ilmu Perairan. Progr Pascasarjana IPB, Bogor. 50 hal.

Burick, J., H. Quick, and T. Wilson,1997. Medicinal attributes of Echinacea spp. Coneflowers. http://www.interme.com/iom/team/n immune.html. 3p.

Craig, W.J., 1999. Health- promoting properties of common herbs. Am J of Clinical Nutrition 70 (3) : 491s-499s.

Effendie, M. I. 1997. Metode Biologi Perikanan. Yayasan Dewi Sri. Bogor. 2003. Kualitas Air Bagi Pengelolaan Sumber Daya dan Lingkungan Perairan. Kanisius. Yogyakarta.

Ellis, A.E. 1998. General Principle of Fish Vaccination. Academic Press. London.

Johnny F, Roza D. 2004. Pengaruh Penyuntikan Imunostimulan Peptidoglikan Terhadap Peningkatan Tanggap Kebal Non Spesifik Ikan Kerapu Macan Epinephelus fuscoguttatus. Jurnal Penelitian Perikanan Indonesia. Vol.5, No 2 Hal. 102.

[KKP] Kementrian Kelautan dan Perikanan. 2016. Statistik Perikanan Tangkap, Perikanan Budidaya, Perikanan Ekspor-Impor Setiap Provinsi Seluruh Indonesia. Pusat Data Statistik dan Informasi. Seketariat Jendral Kementrian Kelautan dan Perikanan. Jakarta. $45 \mathrm{pp}$.

Kueh SG, Netto P, Ngoh-Lim GH, Chang SF, Ho LL, Qin QW, Chua FHC, Ng ML, Fergusson HW. 2012. The pathology of systemic iridoviral disease in fish. J.Com.Path.129: 111-119.

Pais R, Lohs C, Wu Y, Wang J, Aksoy S. Appl. Environ. Microbiol. 2008;74:5965-5974.

Melianawati, R., K, Suwirya. 2010. Optimasi Tingkat Pemberian Pakan terhadap Benih Kerapu Sunu (Plectropomus leopardus). Prosiding Forum Inovasi Teknologi Akuakultur. Jurnal Optimasi Tingkat Pemberian Pakan 1 (2): 659 - 665

Novriadi, R., Haryono, A. Darmawan. 2010. Aplikasi Ekstrak Temulawak (Curcuma xanthorriza Roxb) pada pakan : Studi Komparasi Mutu Pakan Terhadap Pertumbuhan Lutjanus johni dan Lutjanus argentimaculatus. Jurnal Akuakultur Indonesia. Vol.2, No.1

PIOGAMA (Pusat Informasi Obat Universitas Gadjah Mada). 2007. Immunostimulan.http://piogama.ugm.ac.id/index.php/2009/02/imunostimulan

Rahardjo, M., 2000. Echinacea Tanaman Obat Introduksi Potensial. Warta Penelitian dan Pengembangan Tanaman Industri, 6 (2) : 1- 3.

Ridlo A, Pramesti R. 2012. Aplikasi Ekstrak Rumput Laut Sebagai Agen Imunostimulan Sistem Pertahanan non Spesifik Pada Udang Vannamei (Litopennaeus vannamei). Jurnal Ilmu Kelautan. Vol.2.No.7. Hal. 80-90.

Sandes, K. 1991. Studies on vitamin C in fish nutrient. Fisheries and Marine Biology. Univ. of Bergen. Norway. Halaman 32.

Sastrosupadi, A. 1995. Rancangan Percobaan Praktis Untuk Bidang Pertanian. Yogyakarta: Penerbit Kanisius. 
SNI 614.4:2014. 2014. Ikan Kakap Putih (Lates calcalifer, Bloch 1790) Badan Standarisasi Nasional. Jakarta.

Suwirya, K., Giri, N.A. \& Marzuqi, M. 2001. Pengaruh n-3 HUFA terhadap pertumbuhan dan efisiensi pakan yuwana ikan kerapu bebek, Cromileptes altivelis. Di dalam: Sudradjat, A.,E. S. Heruwati, A. Poernomo, A. Rukyani, J. Widodo dan E. Danakusuma (ed). Teknologi Budidaya Laut dan Pengembangan Sea Farming di Indonesia. Departemen Kelautan dan Perikanan. Halaman 201206.

Tjitrosoepomo, Gembong. 1989. Taksonomi Tumbuhan (Schizophyta, Thallopyta, Byrophyta, Pteridophyta). Gadjah Mada University Press: Yogyakarta.

Wijayakusuma H. 2003. Penyembuhan dengan temulawak. Milenia Populer, Jakarta.

Wikipedia. 2008. Hemoglobin. http://www.wikipedia.com. 7 Februari 2008. 